\title{
Efficiency of a submersible plunger pump linear motor
}

\author{
D.A. Chirkov ${ }^{1, *}$ and E.O. Timashev ${ }^{2}$ \\ ${ }^{1}$ PNRPU, Perm, Russian Federation \\ ${ }^{2}$ Oil company "Rosneft", Moscow, Russian Federation,
}

\begin{abstract}
Modern oil extracting has difficulties with extraction at depths exceeding 2 kilometers from mid and low debit wells. Traditional way for extraction from mid and low debit wells (pumping unit) is unacceptable for this task, because of rod column break hazard. Meanwhile, submersible electrical centrifugal pumps that are usually used for oil extracting from big depth have very low efficiency on low debit wells. Due to that, a new class of oil extraction equipment has appeared-submersible plunger pumps. Their world-leading manufacturer is China. The biggest progress in submersible plunger pump linear drive research was reached in Perm National Research Polytechnic University. Although efficiency of this type of pumps on low debit wells is much higher than centrifugal pumps have, it is still very low and does not exceed $30 \%$. Thus, efficiency improvement of gaining popularity submersible plunger pumps is an important task not only for oil extraction but also for energy saving. Major power loss happens in windings of submersible linear motors. Because of that, first step of pump efficiency improvement is improvement of linear drive efficiency. Motor design optimization allows to significantly raise its efficiency to $50 \%$. Higher efficiency could be reached by optimizing motor operation algorithm and using better materials.
\end{abstract}

\section{Introduction}

Nowadays two main oil extraction ways exist: sucker rod pump unit (SRPU) and electrical centrifugal pump unit (ECPU). SRPU is the most effective way to extraction from mid and low debeth wells. It can provide high pressure with range of supply from 5 to $50 \mathrm{~m}^{3} /$ day. Moreover, highest efficiency value - $37 \%$, SRPU reaches with supply $35 \mathrm{~m}^{3} /$ day. But because of rod column break hazard, SPRU can't work on depth more than 2 kilometers. From other side using ECPU is limit oneself to high debeth wells only. At supply less than 80 $\mathrm{m}^{3} /$ day ECPU efficiency becomes less than $35 \%$. Thus, ECPU can't be used with supply less than $40 \mathrm{~m}^{3} /$ day, because of extremely low efficiency. That means, effective oil extraction from depth more than 2 kilometers on mid and low debeth wells can be realized only with absolutely new equipment.

Such equipment is plunger unit with linear motor (PULM) [1, 2]. At pic. 1 PULM layout on well is shown. Linear motor 1 drive motion to plunger of pump 2, which lifts liquid in oil well tubing 3 . Motor supply comes by armored three-core cable 4, which comes across wellhead 5 and connect with control station 6 . Control station is connected to three-phase power supply via transformer 7. PULM include telemetric system 8.

Combining in self possibilities of plunger pump and advantages of submersible motor, PULM presently is main way of oil extraction from mid and low debeth wells on depth from 2 to 3 kilometers. However, despite that PULM significantly outperform ECPU in efficiency for oil extraction from low debeth wells, efficiency of
PULM doesn't exceed 30\% [3]. But it is not the limit of PULM possibilities. Works on the creation of PULM started in 20-s of last century, but constructions of PULM that able to work appeared only in 20 century together with strong rare earth permanent magnets [4, 5]. The biggest progress in PULM developing was reach by Chinese scientists. They designed frequency controlled linear synchronous motor, slider of that contains rare earth permanent magnets.

Simultaneously with China scientists of Perm national research polytechnic university started development of cylindrical linear electronic motor (CLEM) for PULM drive [6-10]. CLEM prototypes designed in PNRPU, have 400 kilograms of tractive force per meter of length [11]. But for apply CLEM in PULM it needs at least 500 kilograms of tractive force per meter.

Rare earth magnets production industry develops every year. More and more strong magnets acceptable for using in submersible pumps appearing [12]. Modern technologies in field of electromagnetical processes modelling allow to determine optimal constructions and work algorithm of electrical motors [13].

\section{Methods}

In goal of CLEM tractive force improving multivariate calculations in ANSYS Maxwell magnetostatic were made for gathering dependences of force from: width, diameter and material of permanent magnets; slot opening; pole pitch coefficient; slider diameter [14].

\footnotetext{
* Corresponding author: chirkov146@gmail.com
} 


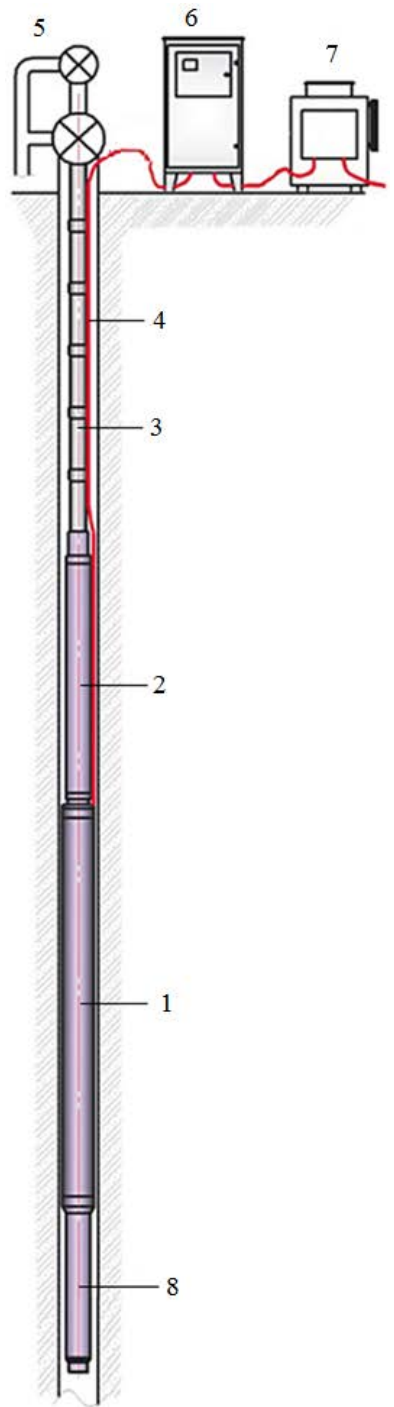

Fig. 1. PULM layout on well.

Model of CLEM that is shown on pic.2, consist of: stator that includes shell 1 , teeth 2 with crown 3 , yoke 4 and three-phase winding 5; slider that includes shaft 6, permanent magnets 7 , poles 8 and non-magnetic rings 9 . Model of CLEM is in vacuum environment 10.

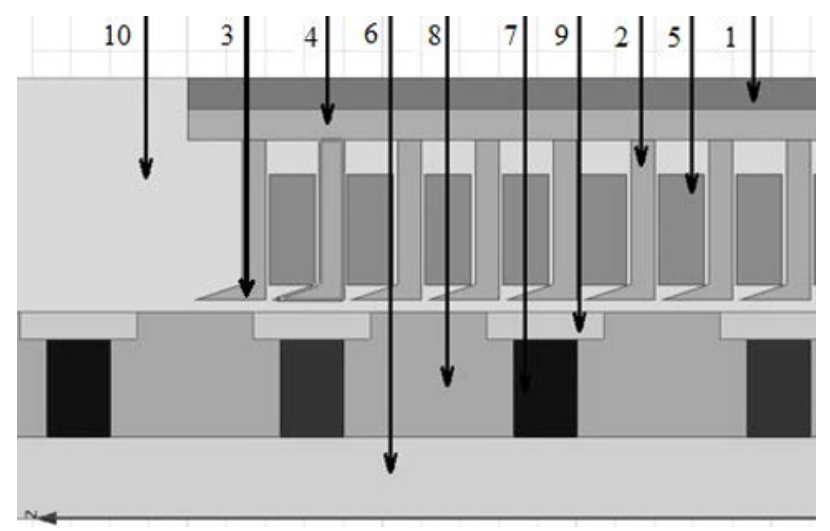

Fig. 2. CLEM model.

Modern technologies in magnet production allow to get materials with residual induction $\mathrm{B}_{\mathrm{r}}$ and coercive force $H_{c}$ in wide range. Because that dependencies from residual induction and coercive force were determined separately. They're shown on pic.3 a), b).

In result of CLEM model calculations with different magnet width $h_{m}$, dependence, that's shown on pic. 4 a), was got. On pic. 4 b) force dependence from magnet diameter $\mathrm{D}_{\mathrm{m}}$ is presented.

As shown on pic. 3 and pic. 4 the highest force is reached with the highest values of all 4 parameters [15, 16]. However, it should be noted that on pic. 4 b growth of force stops at magnet diameter $49 \mathrm{~mm}$. This can be explained by saturation of the magnetic circuit. Force dependency from magnet diameter has quadratic character and steel fast becomes oversaturated. To decrease steel saturation it needs to increase tooth width or change tooth material on one with better magnetic permeability. Anyway changing tooth material is necessary for motor tractive force improvement.

Changing $\alpha_{p}$ has an ambiguous effect on the magnetic circuit. Thus, optimal $\alpha_{\mathrm{p}}$ is exist, which provide maximal force. CLEM tractive force dependence from pole pitch coefficient $\alpha_{\mathrm{p}}$ is presented on pic.5. 


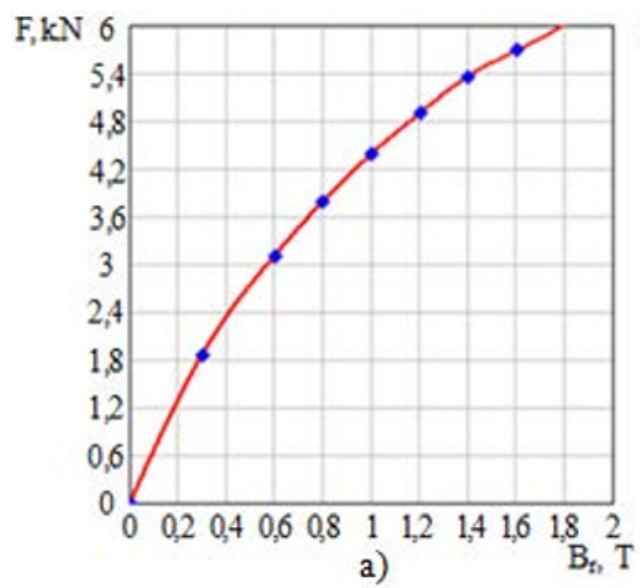

a)

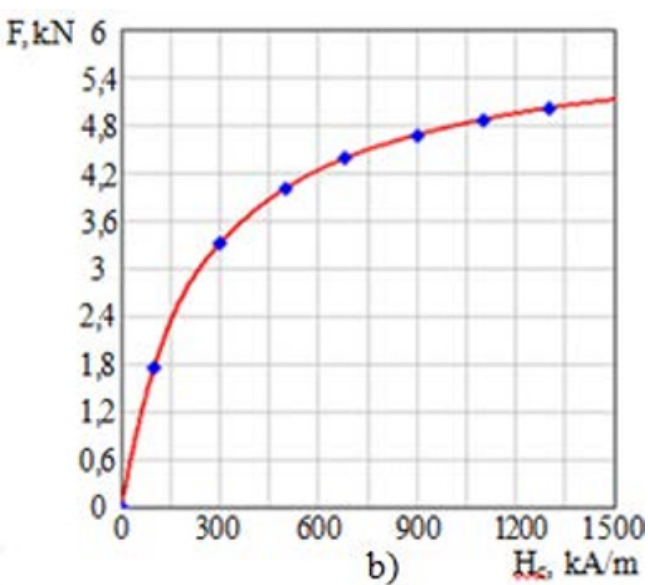

b)

Fig. 3. CLEM tractive force dependencies from: a) residual induction $B_{r}$, b) coercive force $H_{c}$.

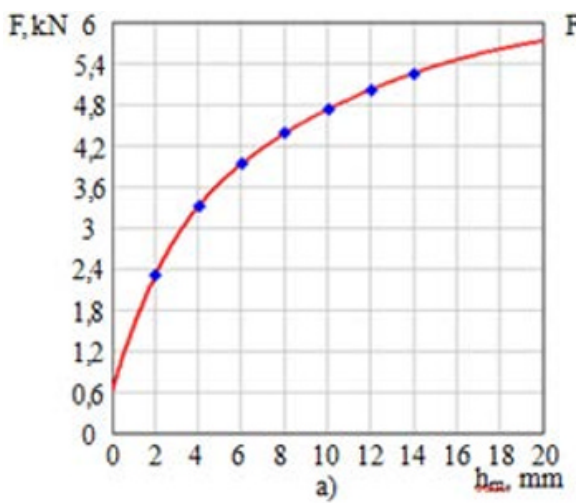

a)

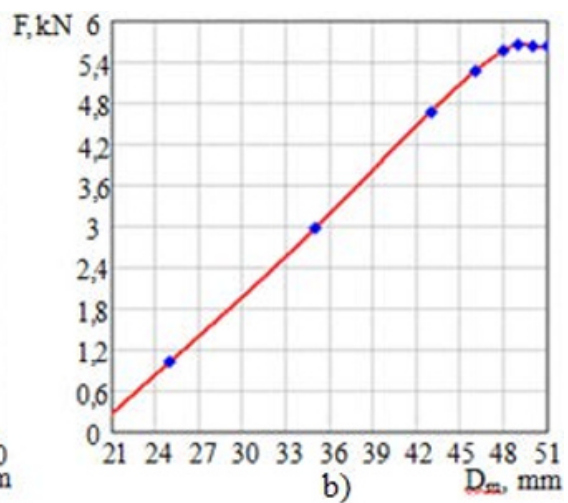

b)

Fig. 4. CLEM tractive force dependencies from: a) magnet width $h_{m}$, b) magnet diameter $D_{m}$.

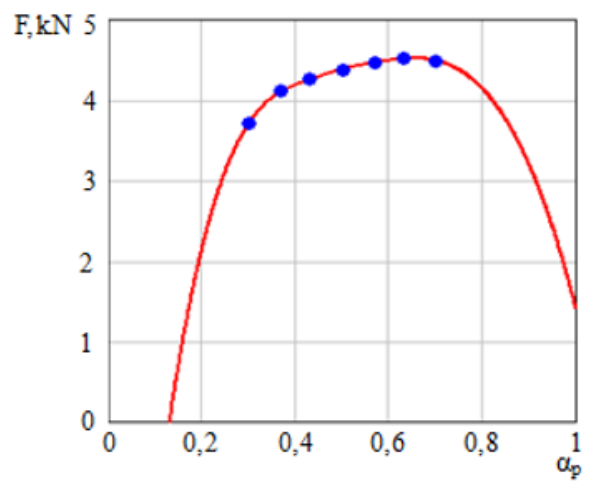

Fig. 5. CLEM tractive force dependence from pole pitch coefficient $\alpha_{\mathrm{p}}$.

Accordingly with pic. 5 at raising $\alpha_{\mathrm{p}}$ from 0.3 to 0.7 , tractive force grows to it's maximum value in $\alpha_{\mathrm{p}}=0.63$ and fall after. $\alpha_{\mathrm{p}}=0.63$ is the optimal value of pole pitch coefficient.

Calculations of force dependence from slot opening shown that with triangle form of tooth crown value of force practically not depends from slot opening. Thus, fully opened slot don't lead to tractive force loss. Fully opened slot allow to make teeth from laminated electrotechnical steel. This will simplify CLEM production technology a lot and allow to significantly increase tractive force.
Calculations of force dependence from slider diameter shown, that without changing magnet diameter changing slider diameter almost don't affect on tractive force. However, changing magnet diameter accordingly to changing slider diameter gives significant difference. Increasing slider diameter without decreasing slot possible only on $2 \mathrm{~mm}$ (size of tooth crown). Further increasing slider diameter possible only with reduction of winding turns number $w$. Dependence of tractive force from winding turns number $\mathrm{w}$ is shown on pic. 6 .

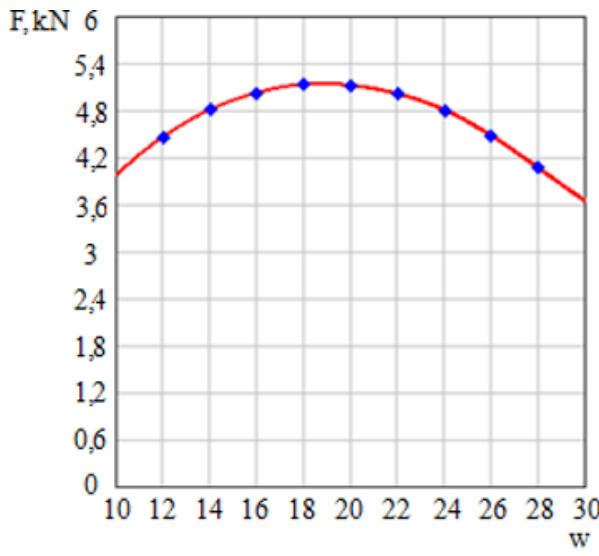

Fig. 6. Dependence of tractive force from winding turns number $\mathrm{w}$. 
Table 1. Comparison of existent CLEM construction with optimal.

\begin{tabular}{|c|c|c|c|c|c|c|c|c|}
\hline \multirow[b]{2}{*}{ № } & \multirow[b]{2}{*}{ CLEM construction } & \multicolumn{2}{|c|}{ Magnet parameters } & \multirow[b]{2}{*}{$\mathbf{F}_{\mathbf{u}}, \mathbf{N}$} & \multirow[b]{2}{*}{$\mathbf{F}_{\mathrm{d}}, \mathbf{N}$} & \multirow[b]{2}{*}{$\mathbf{F}_{\mathbf{u m}, \mathbf{N}}$} & \multirow[b]{2}{*}{$F_{d m}, N$} & \multirow{2}{*}{$\begin{array}{c}\begin{array}{c}\text { Efficiency at } \\
f=7 \mathrm{~Hz}, \%\end{array}\end{array}$} \\
\hline & & $\mathrm{B}_{\mathrm{r}}, \mathrm{T}$ & $\mathrm{H}_{\mathrm{c}}, \mathrm{kA} / \mathrm{m}$ & & & & & \\
\hline 1 & Optimal & 1.47 & 1138 & 2285 & 2715 & 9140 & 10860 & 51 \\
\hline 2 & Optimal & 1.26 & 900 & 2053 & 2337 & 8212 & 9348 & 48 \\
\hline 3 & Optimal & 1 & 680 & 1685 & 1886 & 6740 & 7544 & 42 \\
\hline 4 & Existent & 1 & 680 & 1100 & 960 & 4400 & 3840 & 33 \\
\hline
\end{tabular}

By analysing pic. 6, it's possible to conclude that 18 winding turns allow to produce same tractive force as 20 . Thus, with less magnetomotive force it's possible to gain same tractive force, due permanent magnets increasing. This reduction of winding turns will also reduce general active resistance of motor and accordingly power loss on $10 \%$.

\section{Results and Discussion}

Using all gathered data, new optimal CLEM construction was designed and calculated for three different material of magnets. Calculation results are presented in table 1 .

Maximum tractive force produced by model of existent CLEM construction is $1100 \mathrm{~N}$, which corresponds to 448 kilogram force per meter of length. Maximum tractive force produced by model of optimal CLEM construction with same material of magnets is $1685 \mathrm{~N}$, which corresponds to 688 kilogram force per meter of length. This CLEM is already able to be applied in creation of PULM. With strongest permanent magnets maximum tractive force produced by model of optimal CLEM construction can reach 933 kilogram force per meter. With increasing of traction force motor efficiency is rising. So efficiency of optimized CLEM with stronger magnets can reach value $51 \%$ for frequency of supply voltage $7 \mathrm{~Hz}$. But strongest permanent magnets have work temperature 80 Celsius degrees. This doesn't let to use them in submersible pump for oil extraction, because some oilfields have temperature of oil more than 100 Celsius degrees. Thus, for creating of PULM only magnets with work temperature $200 \mathrm{C}$ and higher can be used. Optimal CLEM № 2 from table 1 have magnets with work temperature 200 C. This CLEM model produce tractive force that corresponds to 838 kilogram per meter.

ANSYS Maxwell magnetostatic can be used comparison different constructions, but it is not suitable for precise calculation of work tractive force of frequency controlled synchronous motor. In this case the closest to real result can be gained by calculation in ANSYS Maxwell transient. Real maximum tractive force produced by model of optimal CLEM construction is 648 kilogram force per meter.

\section{Conclusions}

By multivariate calculations of CLEM the most energy effective construction was gained. Teeth of which are made of laminated electrotechnical steel, due that this CLEM can work on higher supply voltage frequencies.
CLEM operational characteristics analysis for different frequencies shown that working on maximal frequency will provide maximal efficiency of CLEM [17-20]. Optimization of work algorithm and constructive changes that allow CLEM work on even higher frequency are planed further. It will raise efficiency of oil extraction by PULM even higher. But the most important that optimal CLEM construction allow to create PULM that can extract oil from depth more than 4 kilometers, that much higher than abilities of existent PULM of same size.

\section{References}

1. R.I. Bakirov, M.S. Popov, S.M. Berdin, The first experience of plunger pumps with submersible linear electric drive usage in OJSC "NK "Rosneft". Nauchnotekhnicheskiy vestnik OAO "NK "ROSNEFT"'" [OJSC "NK "Rosneft" Scientific and technical bulletin]. M.:Neftyanoe khozyaystvo[Oil industry] 2 72-75 (2016) (in Russian)

2. E.Yu. Vdovin, L.I. Lokshin, V.V. Semenov et. al., Industrial usage of nontraditional technical and technological solutions for oil extraction on oil fields of Perm krai. "Avtomatizatsiya $v$ elektroenergetike $i$ elektrotekhnike”: materialy mezhdunar. nauch.-tekhn. konf. [Proc. Int. Sci. Tech. Conf. Automatization at electric power industry and electrical engineering] Perm, 212-222 (2016)

3. A.T. Klyuchnikov, A.D. Korotaev, The efficiency of the electric motor of a subsurface pump with reciprocating action and losses in a leading-in cable. Russian electrical engineering. Moscow, Znak Publ. 11 (2016)

4. G.I. Izhelya, V.I. Shevchenko, Linear electromotors making, perspectives of introduction to the national economy and their economic effectivity. Elektroprivod s lineynymi elektrodvigatelyami: sb. nauch. tr. vsesoyuznoy nauch. konf. po elektroprivodam s lineynymi elektrodvigatelyami [Proc. all-union Sci. Conf. about linear electric drives with electromotors] Kiev 1320 (1975)

5. L.I. Lokshin, V.V. Semenov, Depth plunger pump with cylindrical induction motor. Elektroprivod $s$ lineynymi elektrodvigatelyami: Trudy vsesoyuznoy nauchnoy konferentsii [Proc. all-union Sci. Conf. Electric drive with linear electromotors] Kiev 2 39-43 (1976)

6. N.V. Shulakov, S.V. Shutemov, Cylindrical linear electronic motor application as drive of oil extracting plunger units. Avtomatizatsiya $v$ elektroenergetike $i$ elektrotekhnike: materialy mezhdunar. nauch.-tekhn. 
konf [Proc. Int. Sci. Tech. Conf. Automatization at electric power industry and electrical engineering]. Perm, PNRPU Publ., 161-167 (2016)

7. A.M. Mirzin, S.A. Beetreu, A.T. Klyuchnikov, A.D. Korotaev, Valve motor control without position sensor. Innovatsionnye tekhnologii: teoriya, instrumenty, praktika (INNOTECH 2013): materialy Mezhdunar. internet-konf [Proc. Int. internet conference Innovative technologies: theory, instruments, practice. INNOTECH 2013]. Perm, PNRPU Publ. 158-166 (2014)

8. D.A. Chirkov, A.D. Korotaev, Cylindrical linear elecrtronic motor main parameters calculation by equivalent circuit. Avtomatizatsiya v elektroenergetike $i$ elektrotekhnike: materialy mezhdunar. nauch.-tekhn. konf [Proc. Int. Sci. Tech. Conf. Automatization at electric power industry and electrical engineering]. Perm, PNRPU Publ. 144-149 (2016)

9. A.T. Klyuchnikov, A.D. Korotaev, N.V. Shulakov, S.V. Shutemov Cylindrical linear electronic motor for submersible rodless pump Avtomatizatsiya $v$ elektroenergetike $i$ elektrotekhnike : materialy mezhdunar. nauch.-tekhn. konf. [Proc. Int. Sci. Tech. Conf. Automatization at electric power industry and electrical engineering]. Perm, PNRPU Publ. 158-162 (2015)

10. A.T. Klyuchnikov, A.D. Korotaev, S.V. Shutemov, Modeling of a cylindrical linear AC electronic motor. Russian electrical engineering. Moscow, Znak Publ. 11 (2013)

11. Korotaev A.D., Shulakov N.V., Shutemov S.V. Experimental research of cylindrical linear electronic motor. Aktual'nye problemy energosberegayushchikh elektrotekhnologiy APEET-2014 : sb. tr. mezhdunar. nauch.-tekhn. konf. [Proc. Actual problems of energy saving electrotechnologies APEET-2014]. Ekaterinburg. UrFU Publ.,198-200 (2014)

12. L.H. Lewis, F. Jiménez-Villacorta. Perspectives on Permanent Magnetic Materials for Energy Conversion and Power Generation. Metallurgical and Materials Transactions A. 33 (2013)

13. Hongbo Qiu, Yuedong Guo, Wenfei Yu, Bingxia Tang, Cunxiang Yang. Research on the Influences of Time Harmonics on Permanent Magnet Synchronous Motors with Hybrid Magnet Poles. Journal of Electrical Engineering \& Technology 14 (2019)

14. N.V. Shulakov, S.V. Shutemov, A method for calculating the electromagnetic processes in a cylindrical linear electronic motor. Russian electrical engineering. Moscow, Znak Publ. 11 (2014)

15. Chirkov D.A., Shulakov N.V., Korotaev A.D. Construction rationalization of cylindrical linear electronic motor. Raduga znaniy: Teoreticheskie i prakticheskie aspekty nauk: materialy mezhdunar. nauch.-prak. konf.[Proc. Scientific and practical Int. Conf. Rainbow of knowledge] Rostov, 101-109 (2019)

16. E.O. Timashev, D.A. Chirkov, N.V. Shulakov, A.D. Korotaev, Secondary element optimization of cylindrical linear electronic motor. Voprosy elektrotekhnologii [Questions of electrotechnology]. Saratov, SGTU Publ. 1 (2019)

17. M.S. Baybakov, A.T. Klyuchnikov, A.D. Korotaev, S.V. Shutemov, Control algorithm of cylindrical linear electronic motor with permanent magnets. Avtomatizatsiya $\mathrm{v}$ elektroenergetike i elektrotekhnike: sb. tr. mezhdunar. nauch.-tekhn. konf. [Proc. Int. Sci. Tech. Conf. Automatization at electric power industry and electrical engineering]. Perm, PNRPU Publ. 13(9) 184-189 (2015)

18. S.V. Shutemov, M.S. Baybakov, A.D. Korotaev, A.T. Klyuchnikov, Control system of cylindrical linear electronic motor of reciprocating Informatsionnoizmeritel'nye i upravlyayushchie sistemy. [Informational-meteric and managing systems] 13(9) 64-69 (2015)

19. E.O. Timashev, D.A. Chirkov, A.D. Korotaev Operating mode of cylindrical linear electronic motor at oil extraction. Vysokie tekhnologii i innovatsii $v$ nauke: materialy mezhdunar. nauch. konf. [Proc. Int. Sci. Conf. High technologies and innovations in science]. St. Petersburg, 76-81 (2019)

20. E.O. Timashev, D.A. Chirkov, A.D. Korotaev, Work characteristics of cylindrical linear electronic motor, obtained by finite element method. Russian electrical engineering. Moscow, Znak Publ. 11 (2018) 